Abstracta Iranica Iranica

Revue bibliographique pour le domaine irano-aryen

Volume 31 | 2011

Comptes rendus des publications de 2008

\title{
«Deconstructing the destruction of Hasanlu ». IA, 43, 2008, p. 89-106.
}

\section{Rémy Boucharlat}

\section{(2) OpenEdition}

1 Journals

\section{Édition électronique}

URL : http://journals.openedition.org/abstractairanica/39190

DOI : 10.4000/abstractairanica.39190

ISSN : 1961-960X

Éditeur :

CNRS (UMR 7528 Mondes iraniens et indiens), Éditions de l'IFRI

Édition imprimée

Date de publication : 15 mai 2011

ISSN : 0240-8910

Référence électronique

Rémy Boucharlat, « «Deconstructing the destruction of Hasanlu ». IA, 43, 2008, p. 89-106. », Abstracta Iranica [En ligne], Volume 31 | 2011, document 52, mis en ligne le 15 février 2012, consulté le 05 octobre 2020. URL : http://journals.openedition.org/abstractairanica/39190 ; DOI : https://doi.org/ 10.4000/abstractairanica.39190

Ce document a été généré automatiquement le 5 octobre 2020.

Tous droits réservés 


\title{
«Deconstructing the destruction of Hasanlu ». IA, 43, 2008, p. 89-106.
}

\author{
Rémy Boucharlat
}

PM revient sur la question de la date de la destruction des bâtiments à piliers d'Hasanlu niveau IVB, si important pour la chronologie de l'âge du Fer II dans l'Iran du NO et audelà (cf. Abs. Ir. 25, $n^{\circ} 84,26, n^{\circ} 96$ ). Question également importante pour l'histoire du royaume d'Urartu. L'A conteste, une fois encore la date de $800 \mathrm{BC}$ donnée naguère de manière trop affirmative sans doute par les fouilleurs, R.H. Dyson et O.W. Muscarella, mais son argumentation, fragile elle aussi, ne lui permet pas d'être convaincant dans le rajeunissement de quelque 50 ans qu'il propose. Discussion sans issue actuellement, puisque cette fouille n'est toujours pas publiée.

\section{INDEX}

Thèmes : 3.2.2. Pré-Achéménides et Achéménides

\section{AUTEURS}

RÉMY BOUCHARLAT

CNRS - Lyon 